\title{
How critical is the global? Discursive shifts in development education in Ireland
}

\author{
Eilish Dillon* - Maynooth University, Ireland
}

\begin{abstract}
This article questions the shift towards the global in discourses of development education in Ireland. Drawing on analysis of policy and research on discourses of development education with facilitators in Ireland, it shows that this shift is neither complete nor necessarily critical. Side by side with talk of the global are discussions of 'development issues' and 'promoting development', with the global often constructed in terms of the Global South and local-global relations assumed to mean North-South. The article examines some dynamics around shifting discourses and argues that the shift to the global does not necessarily signal a more critical development education. As such, it calls for critical analysis beyond changed language used in development education to explore the assumptions that underpin it and its implications for criticality.
\end{abstract}

Keywords: development education; discourses; discursive shifts; criticality, global citizenship education; Ireland

\section{Introduction}

This article explores changing language around development education in Ireland. Specifically focusing on the growing use of terms associated with the global, it questions whether this represents a shift towards the critical in development education or 'more of the same'. It emerges out of doctoral research on development education in Ireland, which was designed to engage with development education facilitators to explore the criticality of development education in Ireland. As a development education facilitator and activist with 30 years' experience in the field in various capacities, most notably among non-governmental development organizations (NGDOs) and in higher education, I was influenced by post-development and critical pedagogy. As such, I applied a critical post-structuralist epistemology and a bricolage approach (Kincheloe and McLaren, 2005) to the research, which drew broadly on critical discourse analysis and involved mixed methods. With its focus on discourses of development education, 21 facilitators responsible for the support and promotion of development education in formal and non-formal contexts, most of whom are active members of the Irish Development Education Association (IDEA), participated in a questionnaire, in-depth interviews and workshops, along with nine key informants involved in state and civil society promotion of development education, who participated in interviews. Aiming to critically analyse discourses of development education, the primary focus of the research was on facilitator talk - language, assumptions and the meanings associated with different aspects of development education. These aspects were knowledge and understanding, skills, learning processes, action and activism, as well as the aims, values and politics of development education. Questions guiding the research focused on 
these aspects of development education, as well as on the institutional and discursive influences on criticality when it comes to development education in Ireland. As such, the research is unique in focusing on the experiences of development education facilitators to critically analyse development education discourses and the structures enabling and constraining development education criticality in Ireland. Comprehensive discussion of the research is outside the scope of this article. Therefore, the article draws on one theme emerging from my research - the shift to the global in discourses of development education.

In recent years, there has been a notable and growing shift away from the language of development education to that of the global, global citizenship education and global education. There has been some move away from talk of 'developing countries' and 'global North-South' relations to discussions of 'globalization', 'global interconnectedness' or 'linking the local and the global'. Central to many contemporary understandings of development education is the notion of a 'global dimension', world or global mindedness (Béneker et al., 2014; Peck and Pashby, 2018) and the element of a 'global outlook' (Bourn, 2015: 30). This shift has been reflective of critiques of the colonial, Eurocentric, modernist and universalist assumptions and implications of traditional development discourses and there is a sense that notions of 'the global' or 'local-global interconnectivity' can reflect more complex and diverse global realities and more egalitarian relationships. The link between the global and citizenship or active citizenship is also designed to signal a move from traditional charity or development cooperation associations to activism based on critical engagement in global structures by locally and globally connected individuals, groups and movements (McCloskey, 2016).

The shift to the global in discourses of development education in Ireland is the focus of this article. Drawing on analysis of policy and research on talk among development education facilitators in Ireland, I highlight that despite this shift, many still either largely or also talk in terms of the 'global North-South', and even where talk is of global interconnections, this is often understood to mean North-South links, with the global constructed as 'other'. Thus, the shift to the global is not complete nor necessarily critical. In this article, I argue that three tendencies in discourse throw light on the dynamics related to shifting discourses from development to the global in development education. The first dynamic is that while language changes, discursive legacies prevail in the meanings and assumptions that underpin them. This is evident in shifting development education policy discourses, discussed below. The second dynamic of interest is that in development education the same terms or concepts can mean many different things. Identified as 'buzzwords and fuzzwords' (Cornwall, 2007), the prevalence of 'floating signifiers' (Moraes, 2014) allows for an 'anything goes' type of politics. This limits critique and promotes new terms that distract attention from problematic, but lingering assumptions and practices associated with outmoded terms. This discursive trend is illustrated below with reference to facilitator talk about development education, as is the third dynamic, the value of discursive critique, resistance and the creation of alternative ways of framing development education.

Below, I explore these dynamics and question the implications of a shift to the global for the criticality of development education.

\section{Understanding discourses and discursive tendencies}

A focus on discourse is important in development education, I argue, because discourses are powerful in shaping thinking, practice and relationships. Discourses are broadly coherent sets of assumptions or patterns of making sense of the world. They 
are frameworks of meaning that form regimes of truth that shape what can and cannot be said (Ryan, 2011).

\section{Language changes but assumptions linger}

There has been a fairly long history of focusing on discourse in relation to development and in development education. Influenced largely by Foucault's work on discourse in post-colonial analysis, early debates in post-development (Escobar, 1984, 1995; Sachs, 1993) focused on whether development discourse was dominant and deterministic or not and whether 'alternatives' would contribute to shifting development discourses, or be co-opted or subsumed by them (Pieterse, 1996, 2001). Where Escobar and Sachs showed the colonizing nature of development discourse, many agree that surface language changes as new terms emerge and are embraced and new framings of old problems seem to offer opportunities for alternative ways of conceptualizing, for example, development, education or citizenship. The question is whether these changes can shift existing core assumptions and relationships associated with dominant discourses or not, for example, in relation to modernity (Andreotti, 2013).

A layered understanding of discourse is helpful in understanding why language can change at the surface but why this does not necessarily change core ontological assumptions. This is an understanding of discourse as sedimented, with various layers or dimensions laid down over years through different institutions, policies and practices, differently in different contexts. In order to understand what the tendencies within development education discourses are in this regard, it is useful to explore discourses in context, as they are contingent on the context within which they are produced and operate, for example, the socio-economic, political, cultural and institutional contexts and they are contested and constructed by actors both within and external to the development education sector. In this way, although powerful, discourses of development education are not static, and contestation and contradictions are common.

The tendency for language to change but assumptions to linger is evident in development education policy discourse in the Irish context. This has led to a melange of various terms and understandings associated with various dimensions of development education in policy, including discursive contradictions associated with language change on the one hand and historical discursive influences on the other. As in other country contexts (Bourn, 2011), there were a variety of influences on discourses of development education in Ireland and the 1970s set the tone for the development education that would follow. Four discourses of development education were established in the 1970s and 1980s, associated with different NGDOs, solidarity groups and the Irish government. The first, according to Fiedler et al. (2011), was a valuebased development education based on global justice and equality, and influenced by liberation theology, structuralist analysis of Global North-South inequalities and the transformative education work of Paulo Freire. The second, a 'solidarity' discourse, emphasized public debate about aid and broader development and human rights issues at the time, as well as issue- and country-specific campaigns and activism. A third discursive strand is called a 'development-as-charity perspective' (Fiedler et al., 2011: 23). Focused on humanitarian concerns and economic development (largely understood in modernization terms) or 'underdevelopment' in 'the countries of the Global South' and drawing its influence from Irish missionary and NGDO development work in countries in Africa and Asia, this perspective involved promoting awareness and understanding for fundraising purposes. There was also the beginning of a state discourse on development education - that is, the framing of development education 
within development cooperation, with emphasis on individual action through overseas development work, working in partnership with voluntary agencies and a focus on development education on development cooperation.

A significant feature of policy discourses of development education in the 1990s and 2000s was the rise of adjectival educations. Discursively, they represent the coming together of influences from international policy as well as domestic politics. From the Rio Conference in 1992, with its emphasis on sustainable development, to the Beijing Platform for Action in 1995 and the 50th anniversary of the UN Declaration of Human Rights in 1998, these adjectival educations were identified as related to development education and were fundable by the Irish government through its development cooperation unit, Irish Aid, under its development education scheme, once they involved a global dimension or perspective. This was reflected in the first government strategy on development education, which was published in 2003, where the link was already made by government between development education and 'Intercultural Education (ICE), Anti-Racism Education (ARE), Multicultural Education and Human Rights Education (HRE). We will encourage the integration of a global and justice perspective in these programmes and policies' (DCl, 2003: 13). In addition, the understanding of development education presented emphasizes 'action for global citizenship and participation' (DCl, 2003: 11). Significantly, in an Irish context, while these different educations were emerging and becoming more associated with the global rather than a singularly North-South framing, they were also regarded as companions to, complementary to, or subsumed under development education.

In recent years, this growing emphasis on the global is becoming even more evident in Irish Aid development education policy, as a simple content analysis shows. In Irish Aid's most recent strategic plan for development education, for example, there is a significant growth in the number of references to the global (from 23 in 2003 and 13 in 2008, to 64 in 2017), including to global citizenship education (from no references in 2003 or 2008, to 13 in 2017). Irish Aid (2016: 32) wishes to support 'communities to discuss, critically debate and engage in active citizenship on the global social, economic and political policies which shape the lives and livelihoods of local people here and around the world'. In exploring the links between global citizenship education and development education, Irish Aid now sees global citizenship education as an umbrella term encompassing development education and education for sustainable development and outlines the role that global citizenship education can play in building common humanity and encouraging activism at local, national and global levels. It suggests that:

the UN SDGs [Sustainable Development Goals] have radically changed our understanding of development, from binaries of 'developed' and 'developing' to the recognition that all countries are constantly developing and transforming, as they respond to emerging global challenges and pursue more sustainable, interdependent societies and economies to ensure the well-being of their citizens. (Irish Aid, 2016: 10)

Despite this linguistic shift, an interesting feature of recent discourses of development education in Ireland, signalled in early tensions highlighted by Fiedler et al. (2011), is the blurring of lines between development education and public engagement. While Irish Aid increasingly sees development education as part of global citizenship education and suggests a movement away from old binary notions of developing and developed, the growing emphasis on public engagement, and on promoting development cooperation as part of development education, seems to contradict this 
move. Although the notion of public engagement is used by both NGDOs and the Irish government, it is largely associated with the promotion of development assistance among the Irish government and of 'ownership of Ireland's development cooperation programme' (Irish Aid, 2006b: 4). Irish Aid (2016: 36) also links development education to this task, identifying in its Development Education Strategy 2017-23, its aim to 'increase awareness and understanding among the Irish public of the work and impact of our aid programme and its contribution to the UN SDGs'. Thus, from an Irish Aid policy point of view, understanding global development issues becomes about uncritical support for development assistance, a North-South framing that assumes the binary notions of development and developing. In this context, although new configurations, framings or signifiers are emerging in Irish development education policy discourses, as the move to the global is accompanied by a deeper focus on the apparently uncritical promotion of development, it represents a contradiction at the very least and more likely a compromise to the potential criticality of development education.

\section{Discursive ambiguities, multiple meanings and contradictions}

Considerations around discursive shifts also benefit from discussions of the application of linguistics. What is meant, for example, by 'the global' or 'local-global relations'? How are global development challenges understood? Recent debate suggests that the terms used in development education are often so general and vague that they can mean anything, or all things to all people. This idea is captured in the notions of 'fuzzwords and buzzwords' (Cornwall, 2007) and 'floating signifiers' (Mannion et al., 2011 and Moraes, 2014). In supporting multiple, ambiguous and contradictory meanings, they can lead to the uncritical and apolitical adoption of new terms and trends with little exploration of the meanings and implications associated with them.

Building on the exploration of concepts related to development in the Development Dictionary (Sachs, 1993) and Cornwall (2007: 471) argues that 'words make worlds', highlighting that the taken-for-granted quality of development 'leaves much of what is actually done in its name unquestioned'. Showing that buzzwords have become fuzzwords, Cornwall (2007: 474) suggests that 'buzzwords provide concepts that can float free of concrete referents to be filled with meaning by their users'. This notion of concepts or terms that 'float free' and that can have multiple meanings is also explored by Mannion et al. (2011) and Moraes (2014) in relation to education for global citizenship. Mannion et al. (2011) draw on Lacalu and Mouffe's idea of a nodal point to describe the fact that education for global citizenship can involve a range of different understandings and perspectives, some critical and others more liberal or developmentalist, depending on the context and the power relations shaping how education for global citizenship is understood in a particular field.

Thus, the notions of floating signifier and buzzword give some indication of the power of concepts and terms to take on multiple, ambiguous and often contradictory meanings or discursive assumptions. The question of why and how is a more complex one. Ziai (2015) highlights techniques that continue to be pervasive in discourses of development and that serve to reinforce its legitimization rather than question it. Like the others, he highlights 'the shifting of signifiers. It builds on the polysemy of the term "development"' (Ziai, 2015: 10). In simple terms, this means that the term can be used to mean different things - for example, capitalist, economic development on the one hand, and improvement in living standards on the other. In the context where it can be used to mean both, he argues that it appears to lose the contradictions 
involved whereby one application can prohibit the realization of the other. He goes on to show how assuming positivity also displaces attention from problems with the notion of development itself and transfers them on to problems with the technical realization of it. Arguing that it puts development beyond criticism, new approaches to development (or, in this case, reframings of development education in terms of the global) emerge without challenging the ontological problems associated with it, such as Eurocentrism or notions of progress. Ziai (2015) argues that the language of development depoliticizes, in that there is an assumption that it benefits everyone. Based on 'helping the poor' without 'hurting the rich', Ziai (2015: 13) argues that 'it has to do so in order to gain support and legitimacy, but in doing so neglects an analysis of the structural causes of poverty and depoliticizes the conflicts and divisions in society'. He argues, following Gasper (1996), that the 'discourse works through the "concealment of divisive issues"' (Ziai, 2015: 14). In this context, although often regarded as positive and critical, the shift to the global is slippery and is associated with multiple meanings, ambiguities and contradictions.

The discursive tendency for the same terms to have different meanings, to act as 'fuzzwords' and 'floating signifiers' is very much reflected in development education facilitator talk about the global in development education, where the terms 'global' and 'local to global connections' are used in different, and sometimes contradictory, ways. This can hide the problematic assumptions associated with some uses, while making them difficult to question.

\section{Methodology}

As indicated earlier, in-depth interviews were carried out with 21 development education facilitators and nine key informants, all of whom are involved in the promotion and support of development education in formal and non-formal education contexts through NGDOs, community education or development education organizations, or with state-run or supported organizations. Interviews were carried out in 2016 and were transcribed and analysed using the MAXODA software. Two approaches were applied to analysing the key themes emerging: a statistical content analysis compiled the frequency of reference to specific terms in interview talk and a discourse analysis approach identified concepts, themes and terms with reference to an analytical framework developed from the literature. Given limitations of space, here I draw on these interviews to provide just a few examples and statistics that illustrate the discursive tendency towards ambiguity, multiple meanings and contradictions. Pseudonyms are used throughout and as I quote from interviews below, I indicate the main context within which the person promotes development education: formal education (FE); NGDO; development education organization (DEO); network (N); or community education (CE).

\section{Different understandings of the global among interviewees}

In interviews, when it comes to understandings of the global, the most frequent use of the term applies to 'global citizenship education', 'global education' or 'global learning', with 55 references in total among 13 of the 21 development education facilitators interviewed. The global is also understood quite frequently in terms of 'the global world' or 'globalization' (51 references among 12). There are references to local-global connections (by 15), to global justice, equality, poverty and development issues (by 14), to global citizens or global citizenship (by 10) and references to global solidarity and community (by 4). 
Talk of the global in interviews emerges most significantly with reference to discussions of knowledge and understanding developed through development education, as well as in relation to skills. Exploration of global development issues is mixed, with some focusing on the 'development' aspect and others on their understanding of the 'global'. For Niamh (FE), for example, 'a lot of development issues would be, let's say, development topics would be things around trade, aid, debt, you know, poverty, hunger, but I think in development education because you're incorporating that local aspect as well'. Focusing on the global, for Maeve (FE), 'the ultimate goal of having a student that's well-rounded and having a good understanding of what they need to do as global citizens'.

Among some development education facilitators, understanding the global is framed in terms of understanding global 'problems' and facilitating a response to them. Tom (DEO) says that 'we're always dealing with the manifestations of problems, drought, poverty, migration, but we're very rarely looking at the factors that cause these things, like climate change, like Western-led wars, like the arms trade, like unfair trade policies, like debt'. For Catherine (FE):

development education is a vehicle for an active response to issues of injustice. It's a really effective way of stopping you feeling paralysed, so this is happening in the world. What does it mean? Why is it happening and what can I do about it? And then, the response to that.

When it comes to development education skills, the skill of making connections is central for nearly all development education facilitators interviewed (20 of 21), with making local-global connections specifically mentioned by 15 of the 21 . These localglobal connections are understood differently among facilitators involved in the research. The most frequent reference (11 facilitators) is to understanding local-global connections in terms of seeing development issues as having local-global dimensions and connections. In this context, global issues or contexts, such as the global economy, climate change, migration or refugees - all issues mentioned by facilitators - are regarded as having local and global dimensions. Some facilitators talk of local-global connections with an emphasis on local issues as important in themselves (9) and others regard 'the local' as an 'entry point' for issues or action at a global level (7). The effects of local actions on 'the global' were talked about by 7 facilitators, and 2 talked about the importance of focusing on local-global connections in order to shift problematic North-South constructions of development relationships. Thus, constructions of the local-global are not simple and the implications of the assumptions that underpin them cannot be assumed.

Among those who talk about local-global connections, 4 are critical of the relative lack of links at this level in development education, with 3 being critical of localism or an underemphasis on global links to local issues and the other being critical of the superficiality of local links in a lot of development education. For some, localglobal connections are about developing global mindedness or developing a global outlook. Again, what this involves is understood differently. Anne (FE) says: 'it's about getting people to reflect, to critique, to connect'. Bríd (FE) sees the local and global connections in terms of critical thinking leading to action:

the global is central, but what makes development education development education, to me, is students having the capacity to think critically and reflect on how things are globally but also locally. Like you have to tie 
the two together ... So it's the action component to me is what makes development education development education.

Although some facilitators construct local-global connections as interlinked, others view them in binary terms, with the local representing their own place, community or context and the global representing the other or, as is often the case, the Global South. This is the case for Patrick (NGDO):

I mean the scale, like in terms of human suffering, the scale in sub-Saharan Africa is so much worse. The poverty, the sickness, the quality of life, the child mortality. All of that is so much worse at that level and it would be wrong, I think, for us to forget that and we can't solve that simply by dealing with issues at home all the time.

Robert (NGDO) talks about using local examples from Ireland and around the world to throw light on the experience of people in the Global South and to encourage activism here in Ireland:

because you're mobilising the Irish public to support our work overseas, and you cannot do that if there's a disconnect ... if we're going to explore rights and responsibilities around these different social justice issues then it must be grounded in what's recognizable to them, which is the Irish experience first of all, then it's overseas after that.

Niamh (FE) applies two understandings of local-global connections. On the one hand, she suggests that the local acts as a way in to understanding the global, whereas on the other she argues that 'in an increasingly globalized world, it makes sense not to look at issues in isolation. ... 'Cause I think that that helps challenge a sort of an ethnocentric approach that people have'. For seven of the development education facilitators interviewed, a key skill when it comes to local-global connections is understanding the effects of how people live in the Global North on people in the Global South. For Liam (DEO):

the problem is here. The problem is not out there. The problem is here and if we don't invest in education and formation, and stimulation and argument and debate here, then we're just fools who are just letting on that the problem is in all of the world. The problem is not in all of the world. The problem is the rich of the world. We all know this.

Thus, there are a variety of understandings of the global and local-global connections applied by development education facilitators, but some clearly view the global - and often the Global South - as the other and many assume that the local means Ireland or the Global North. While some development education facilitators seek to challenge stereotypes associated with development constructions, others wish to retain NorthSouth notions to encourage responsible action at a global level.

\section{Discursive contestations and alternatives}

The third discursive issue of relevance is understanding how discourses are structured, how they work and how they can be contested and changed. This is an important task for the discourse analyst, activist or 'reflective practitioner' (Ryan, 2011). Escobar's (1984: 379) early work is insightful in highlighting the contribution from Foucault of a genealogical approach to: 
undertake a diagnosis of a current situation by concentrating on the political technologies constituted by the interrelationship of contemporary forms of power and knowledge. The objective of his study are those practices of modern culture embodied in specific technologies, their localisation in different discourses, institutions and disciplines, and the processes by which they arise and develop.

Ryan (2011) argues that discourse analysis plays an important role in identifying the assumptions and premises of different discourses. This, she feels, offers the discourse analyst the ability to decide which discourses are enabling and which ones need to be challenged. Similarly, Cornwall's (2010) aim is to challenge what is taken for granted in development. Cornwall (2010: 14) argues for a 'constructive deconstruction' approach, which reveals ideological differences and 'opens up the possibility of reviving the debates that once accompanied the use of bland, catch-all terms like civil society and social capital'. In focusing on how development discourse has appropriated and hybridized other critical concepts, Ziai (2015: 16) argues, following Cornwall, that if it can do that, then through a 'constructive deconstruction' it offers 'the possibility of resignifying the term "development"'.

Within the context of the research conducted with development education facilitators, many were critical of the role of development education in perpetuating development assumptions, while also seeing the potential of development education to challenge what they see as limiting or problematic development assumptions or relationships. Many of the different assumptions associated with the shift to the global have been explored in earlier sections. Here, I focus briefly on alternatives. For Áine (FE), for example, an important role for development education is in challenging development stereotypes. Áine identifies them as:

injustice, discrimination, inequality at a global level, the kind of economic, the disparities in the world in terms of poverty and wealth, and how that works. And, you know, how, I suppose, another issue is ... a lot of us have been brought up with is the charity mode of, you know, 'we're very charitable people. We're great at giving and so, you know, we can't be blamed for the poverty in the world because we're so generous'. But actually, that is an issue in itself, the narrative of charity, so bursting that open a bit and talking that through and understanding how that works as well to salve our own consciences, and the fact that we benefit from this inequality.

Drawing on the SDGs and the language of local-global connections, interviewees talk about the need to move away from North-South development assumptions, to embrace more critical community-based links between local and global realities and the need for development education to be critically reflexive. Kathleen (N), for example, argues that 'development education can be really depoliticizing and empty out the analysis that needs to be part of education work'. She argues for an approach that is:

about linking the local and the global, and the local crisis that we're living through and the global crisis that people further away have been living through for much longer. So, there was, instantly, a different dynamic because the people we were working with were really, really angry from the outset, and were coming to meetings with a view to organizing, so they wanted education as a route to changing things. It was like a very different starting point. They were much more ready and they had much 
more at stake, because they were groups working with communities and individuals that were losing out so much as a result of austerity here ... So the education work became much more dynamic, much more urgent, in terms of people's participation and engagement.

In talking about the need for development educators to address 'the elephants in the room', Liz (DEO) mentions debt cancellation and Ireland, racism, and:

the local-global thing that this slogan, when I came to this kind of work initially that was like a bumper sticker, obviously, because we were saying it, everyone, it was just paraded out everywhere, 'we link local and global issues', and how facile the local links really are in practice most of the time!

Dan (CE) was also critical of a lot of the focus of development education, which he sees as being:

about something else, somewhere else in the world. So, it's not as immediate. So, development education is abroad, you know, but if your abroad is at home, it changes your mind. So, it's like, it's not another group of people you're working for, it's this group. I think that has influenced me in the sense that whatever group I'm working with, there's a developmental educative bit with that group.

Here, both Liz and Dan give some indication of the need for alternatives when it comes to the framing of development and education within development education practice. Where Áine (FE) talks about the need to 'turn education upside down', others highlight the need to interrogate the values and politics of development education, the role that development education can play in critically analysing its own assumptions and representations and the importance of questioning truth claims when it comes to values and politics.

\section{Reflections on the implications for criticality}

As suggested above, one of the tasks for the discourse analyst is to try to understand the implications of different discursive premises for criticality. Before exploring some implications of the discussion of discursive dynamics, I reflect on the meaning of criticality in development education. There has been a lot of debate in recent years about what constitutes criticality in development education or global citizenship education (Andreotti, 2006, 2013, 2014; Bryan and Bracken, 2011; Todd, 2015; Biccum, 2015; Khoo and McCloskey, 2015; McCloskey, 2016). The research referred to here, influenced by this debate, drew on facilitator talk to identify understandings of criticality in development education in Ireland. In most cases, as evident in my research, development education facilitators talk of development education in critical terms, while ambiguities and contradictions are also evident. Most strive for a move away from North-South, charity or trusteeship constructions of North-South relations to a conception of greater global interconnectedness, equality, complexity and diversity. Trying to reflect the politics of desired change, there are attempts to hold in tension such critiques with questioning the value and political basis for criticality.

Two understandings of criticality emerged in my research with regard to understandings of development education among facilitators: a critical and a postcritical discourse. Although I am unable to explore these in detail here, briefly drawing on my research, a critical discourse of development education assumes that relationships are more complex than North-South. They are understood in 
local-global terms and in terms of interconnectivity and they are framed in the context of processes of globalization. As such, this discourse can be seen to be based on a relational ontology (Benjamin, 2015). In a context where everything is seen in terms of connections, this discourse carries the assumption that the personal and the political cannot be separated and that power relations are complex. Here, similar to critical pedagogy, the assumption is that a critical form of development education can facilitate the understanding, skills and active global citizenship necessary to address global justice, inequality and poverty. At the same time, talk of active global citizenship can often end up involving liberal types of political engagement and activism, rather than more critical and collective ones (Khoo, 2006; Gaynor, 2016). This point is made by a number of participants in this research and it is also raised by Khoo and McCloskey (2015), who question whether development education lives up to its radical potential.

Where a critical discourse of development education identifies connections, structural power and the importance of critical reflection, as identified in my research, a post-critical discourse tries to capture the complexities of global relationships, discourses and development processes, as well as opening up questions about these relationships, discourses and processes in themselves. Here, the focus is not on 'out there' or the 'other'; it is on developing skills to hold complex, diverse and sometimes contradictory realities in tension (Todd, 2009). Critically deconstructing development education itself and its aims, assumptions and narratives of change, a post-critical discourse involves questioning whether development education, as it is critically or otherwise constructed, offers the range of perspectives and alternatives required for the diverse, multi-faceted and complex realities of today's world. Some participants in my research reclaim the term 'Third World', seeking a clarity of politics associated with a North-South discursive framework. In so doing, they challenge the more complex, fluid and diverse politics associated with a post-critical discourse. This type of politics tries to hold in tension centres of power, agency, structures and institutions that dominate, as well as alternatives and unpredictability (Todd, 2015).

In light of these two understandings of development education criticality, the question remains, how critical is the shift to the global in discourses of development education? Key points emerging from the discussion of discursive tendencies above, highlight that while language changes, assumptions, practices and relations can remain much the same. Thus, although a shift from the developmental to the global or, for example, from the Millennium Development Goals (MDGs) to the Sustainable Development Goals (SDGs), with their associated universal terminology, can signal potential criticality, this is not always the case. A key question is why some terms and assumptions change whereas others remain stubbornly resistant to change. My research highlighted the importance of understanding historical organizational and policy discursive legacies that frame meanings, assumptions and relationships in very deep and often taken-for-granted ways. In so doing, it showed that where language has changed to the global, many of the problematic colonial assumptions still linger in development education in Ireland. Although development can be associated with radical forms of justice and human rights, it is also associated in policy with uncritical support for development assistance. This kind of thinking is replete with hierarchies and 'othering' and is often based on vertical axes and binary notions of marginalization, poverty and underdevelopment alongside wealth, progress and development. Development education that conflates the global with binary notions of development assistance or North-South relations maintains, rather than challenges, the ontological status quo (Andreotti, 2013). 
A second implication of the discursive dynamics discussed here is that the new language and the terms we use in development education can allow for apolitical constructions of justice, politics, values and activism. While the language of the global seems more inclusive and seems to acknowledge complexities, structural inequalities and responsibilities in a way that the language of development often fails to do, as evident in my research, it is often used as a substitute for, rather than an alternative to, North-South relations and practices. Where development can often be criticized for Eurocentrism, or for patronizing or trusteeship connotations and practices, the language of the global is less easily criticized in this way.

A third implication of the discussion here is the significance of understanding the context within which development education is practised and the limits and opportunities for criticality in that context. In short, my research with development education facilitators identified three key factors that have shaped development education discourses and practices in Ireland. The first is the influence of the organization and discursive history of development education with its various strands that were laid down over many years and that are still evident today. Difficult to shift, many of these discursive assumptions have become core to Irish identity when it comes to development - for example, the notion of Ireland as a 'generous nation'. These discursive legacies have been mediated, shaped, and sometimes recast, by a variety of state and civil society actors over the years in the context of the second major influence, that of international policy. In that context, the influence of the OECD Development Assistance Committee, the MDGs and SDGs, aid effectiveness, new managerialism and recent efforts to promote 'Irish Aid Works' are a few notable examples. The third major influence on development education discourses comes from actor positions and relations in the development education field itself. Research conducted with facilitators in Ireland highlighted what many know anecdotally, and what others in Ireland (Khoo, 2011) and elsewhere (Pais and Costa, 2017) have identified, the influence of Irish Aid or state power over the development education field. With its growing emphasis on promoting support for development cooperation, it is not surprising that North-South development assumptions remain strong.

Understanding shifting discourses, as well as the assumptions that underpin them and the power relations associated with them can be very challenging. This is especially so for development practitioners, facilitators and academics who believe in the potential criticality of development education, because it forces us to look beneath the surface of language to understand its meanings, and why some changes are only skin deep. Some development educators are doing just this. They are drawing on the critical-reflexive role that development education can play in challenging development assumptions and stereotypes and questioning politics and values of development education. As such, they are pointing to possible alternative critical roles that development education can play.

\section{Conclusion}

Although there are many problematic assumptions associated with a North-South discourse of development education, one thing this article has tried to show is that simply replacing the language of development with that of the global does not necessarily challenge the assumptions associated with development about the world, poverty, us and them, or relationships constructed in its name. Indeed, this focus on the global and on shifting discourses, opens up deeper questions about the starting points for considerations of critical global education (Todd, 2015) and about 
the idealization often infused in new or alternative approaches, for example, global citizenship education, global education and education for global citizenship.

It also opens up questions about the constraints and opportunities offered by the contexts within which development education is practised today. This is particularly important in the context of concerns about the influence of neo-liberalism in education and questions about whether global citizenship education is used as a critical smokescreen for the commodification of formal education (Pais and Costa, 2017). Arguably, when it comes to development education in Ireland, the influence of development cooperation allows for the continuation of development assumptions, albeit wrapped around a discourse of the global. In order for activists, facilitators and academics to have any chance of contesting the development past in the global present, we need to understand where it is coming from and the power relations that keep it in place. Viewing the shift to the global with a critical eye, as I have tried to do in this article, does not mean that a global reframing is not worthwhile. It does imply, however, that we cannot assume that shifts in language, whether it is to the global, to global citizenship education, or in relation to the SDGs, necessarily represent critical development education. Although these shifts may offer critical potential, as in all other aspects of development education, criticality cannot be taken for granted.

\section{Notes on the contributor}

Eilish Dillon coordinates the MA in international development at the Department of International Development, Maynooth University, Ireland. She has been actively involved in development education for 30 years and has recently completed a doctorate in higher and adult education, focusing on discourses of development education in Ireland.

\section{References}

Andreotti, V. (2006) 'Soft versus critical global citizenship education'. Policy and Practice: A Development Education Review, 3, 40-51.

Andreotti, V. (2011) Actionable Postcolonial Theory in Education. New York: Palgrave Macmillan.

Andreotti, V. (2013) 'Renegotiating epistemic privilege and enchantments with modernity: The gain in the loss of the entitlement to control and define everything'. Online. www.umassed.edu/ seppce/centers/cfpa/ (accessed 21 August 2018).

Andreotti, V. (2014) 'Critical literacy: Theories and practices in development education'. Policy and Practice: A Development Education Review, 19, 12-32.

Béneker, T., van Dis, H. and van Middelkoop, D. (2014) 'World-mindedness of students and their geography education at international (IB-DP) and regular schools in the Netherlands'. International Journal of Development Education and Global Learning, 6 (3), 5-30.

Benjamin, A. (2015) Towards a Relational Ontology: Philosophy's other possibility. Albany: State University of New York Press.

Biccum, A.R. (2015) 'The politics of education for globalisation: Managed activism in a time of crisis'. Australian Journal of International Affairs, 69 (3), 321-38.

Bourn, D. (2011) 'Discourses on development education'. Paper presented at the European Association of Development Research and Training Institutes (EADI) General Conference, 'Rethinking Development in an Age of Scarcity and Uncertainty: New values, voices and alliances for increased resilience', University of York, 19-22 September 2011.

Bourn, D. (2015) 'From development education to global learning: Changing agendas and priorities'. Policy and Practice: A Development Education Review, 20, 18-36.

Bryan, A. and Bracken, M. (2011) Learning to Read the World? Teaching and learning about global citizenship and international development in post-primary schools. Dublin: Irish Aid.

Chouliaraki, L. (2008) 'Discourse analysis'. In Bennett, T. and Frow, J. (eds) The SAGE Handbook of Cultural Analysis. London: SAGE Publications, 674-98. 
Cornwall, A. (2007) 'Buzzwords and fuzzwords: Deconstructing development discourse'. Development in Practice, 17 (4-5), 471-84.

Cornwall, A. (2010) 'Introductory overview - buzzwords and fuzzwords: Deconstructing development discourse'. In Cornwall, A. and Eade, D. (eds) Deconstructing Development Discourse: Buzzwords and fuzzwords. Oxford: Oxfam, 1-18.

DCl (Development Cooperation Ireland) (2003) Deepening Public Understanding of International Development, Development Education Strategy Plan 2003-2007. Dublin: Department of Foreign Affairs/lrish Aid.

Escobar, A. (1984) 'Discourse and power in development: Michel Foucault and the relevance of his work to the Third World'. Alternatives, 10 (3), 377-400.

Escobar, A. (1995) Encountering Development: The making and unmaking of the Third World. Princeton, NJ: Princeton University Press.

Fiedler, M., Bryan, A. and Bracken, M. (2011) Mapping the Past, Charting the Future: A review of the Irish Government's engagement with development education and a meta-analysis of development education research in Ireland. Dublin: Irish Aid.

Foucault, M. (1972) The Archaeology of Knowledge. Trans. Sheridan Smith, A.M. London: Tavistock Publications.

Gaynor, N. (2016) 'Shopping to save the world? Reclaiming global citizenship within Irish universities'. Irish Journal of Sociology, 24 (1), 78-101.

GENE (Global Education Network Europe) (2015) Global Education in Ireland: The European Global Education Peer Review Process national report on Ireland. Global Education Network Europe.

Irish Aid (2016a) Irish Aid Development Education Strategy 2017-2023. Dublin: Irish Aid.

Irish Aid (2016b) Annex 2 Programme Grant II Public Engagement and Development Education Guidance, April 2016. Dublin: Irish Aid.

Khoo, S. (2006) 'Development education, citizenship and civic engagement at third level and beyond in the Republic of Ireland'. Policy and Practice: A Development Education Review, 3, 26-39.

Khoo, S. (2011) 'The shifting policy landscape of development education'. Policy and Practice: A Development Education Review, 13, 1-10.

Khoo, S. and McCloskey, S. (2015) 'Reflections and projections: Policy and Practice ten years on'. Policy and Practice: A Development Education Review, 20, 1-17.

Kincheloe, J.L. and McLaren, P. (2005) 'Rethinking critical theory and qualitative research'. In Denzin, N.K. and Lincoln, Y.S. (eds) The SAGE Handbook of Qualitative Research. 3rd ed. Thousand Oaks, CA: SAGE Publications, 303-42.

Mannion, G., Biesta, G., Priestley, M. and Ross, H. (2011) 'The global dimension in education and education for global citizenship: Genealogy and critique'. Globalisation, Societies and Education, 9 (3-4), 443-56.

McCloskey, S. (2016) 'Are we changing the world? Reflections on development education, activism and social change'. Policy and Practice: A Development Education Review, 22, 110-30.

Pais, A. and Costa, M. (2017) 'An ideology critique of global citizenship education'. Critical Studies in Education, 1-16. Online. www.tandfonline.com/doi/pdf/10.1080/17508487.2017.1318772?need Access $=$ true (accessed 13 August 2018).

Pashby, K. and de Oliveira Andreotti, V. (2016) 'Ethical internationalisation in higher education: Interfaces with international development and sustainability'. Environmental Education Research, 22 (6), 771-87.

Peck, C.L. and Pashby, K. (2018) 'Global citizenship education in North America'. In Davies, I., Ho, L.-C., Kiwan, D., Peck, C.L., Peterson, A., Sant, E. and Waghid, Y. (eds) The Palgrave Handbook of Global Citizenship and Education. London: Palgrave Macmillan, 51-65.

Pieterse, J.N. (2001) Development Theory: Deconstructions/reconstructions. London: SAGE Publications.

Ryan, A.B. (2011) 'Discourse: Some considerations for the reflective practitioner'. In Walsh, T. (ed.) The Reflective Practitioner. Maynooth: MACE.

Sachs, W. (ed.) (1993) The Development Dictionary: A guide to knowledge as power. London: Zed Books.

Todd, S. (2009) Toward an Imperfect Education: Facing humanity, rethinking cosmopolitanism. Boulder, CO: Paradigm Publishers.

Todd, S. (2015) 'Creating transformative spaces in education: Facing humanity, facing violence'. Philosophical Inquiry in Education, 23 (1), 53-61.

Ziai, A. (2015) The Contribution of Discourse Analysis to Development Studies (Development and Postcolonial Studies Working Paper 1). Kassel: University of Kassel. 